\title{
Expectation of UAE Tamil Expatriates before Expatriation
}

\author{
Lija. P, R. Radhika
}

\begin{abstract}
In this scenario the role of expatriation are more challenging, the reason of people receive the expatriation is earn money. The current study aims to understand the reason of expatriation, know the expectation of expatriates and know the experience of expatriates. Expatriate thought, feeling and opinion were the target data. Based on a questionnaire that was developed from the literature review, responses from 60 expatriates who are working in Construction Company in Dubai. The reason of the expatriation is overcome from the financial constrain and the expectation of the expatriates would like to receive particular support as well as.
\end{abstract}

Keywords-Reason, Expectation, Experience, Expatriates

\section{INTRODUCTION}

With the wide variety of global assignments continuing to increase, it is essential to detain why people receive to be expatriated. Surely, being an expat includes a number of important stressors in existence, such as transferring among international locations, beginning a new job or project, adjusting to a new lifestyle, and having to build new relationships. Why is it worthwhile to tolerate these challenges? The answer is easy: the advantages generally balance the costs.

From an expert point of view, an expatriate expects their contract regularly includes an attractive repayment package deal, so the relocation can be financially fine. We can additionally gain developmental or promotional possibilities, so the transfer can increase our expectations professional career. However, there are several advantages that move beyond the real expatriate task. In a way, an international task offers a lifestyle modify. We get to enjoy a new culture, may additionally we can learn new language and make international friends, so expatriation is culturally enriching. Furthermore, it involves many opportunities for discovery and journey, creating a live overseas a non-public development enjoy. The followings are some expectation of expatriates.

\section{Learning a foreign language}

"Fluent English": who did not dream of penning this mention on his resume and that it is genuine? Many people join "current English" without always manage with a conversation. English which stays the most broadly spoken language in the international, whether together with your professional life or with the aid of meeting other foreign expatriates.

\section{Seizing new career possibilities}

If you are unemployed or younger graduate, then going abroad can let you find a task greater easily. If it is your business enterprise who proposes to you to expatriate for the task, it might be to recommend a function with more responsibilities or to adapt in the hierarchy. Jump on the occasion! To refuse would be to deprive yourself of a brilliant possibility to accelerate your career.

\section{More attractive salary}

When you have the opportunity to depart as an expatriate on your commercial enterprise, then you'll definitely advantage from a totally secure salary similarly to accommodation on site in case you are going for a private and professional revel in, you may have the Possibility to find an equal job better paid but take a look at the cost of living within the country before heading into your assignment.

\section{Opening up to new cultures}

In expatriation, it's miles an entire new culture that you'll find out! Starting with the language, history, customs, food and customs of the chosen country. Its miles an possibility to take a new look at the sector, to understand situations differently. You will genuinely experience new experiences with a view to open up new horizons and alternate your approach to positive conditions. Humans will not necessarily suppose the same manner you do. Being open will let you better understand this new lifestyle and to kowtow better.

\section{Towards a better quality of life}

If you locate that your existence is at one hundred according to hour, you sense such as you aren't taking part in something, no longer being flourishing in your gift life. Individualism, loss of change and sharing: it weighs you down. The unbridled existence of massive towns now not fits you. Maybe you simply need to pass and live in some other place, but it is also possible that it is abroad that you locate your happiness, expatriation can repair you flavor of small pleasures. If it is not a query of idealizing the united states of your desires, it could correspond to you more.
Revised Manuscript Received on October 25, 2019.

Lija. $\mathbf{P}^{* 1}$,Faculty of Management Studies, Noorul Islam Center For Higher Eductaion, Kumaracovil, Tamilnadu.

Corresponding Email:lijajohn.mba@gmail.com

Dr. R. Radhika ${ }^{* 2}$ Faculty of Management Studies, Noorul Islam Center For Higher Eductaion, Kumaracovil,Tamilnadu. 


\section{Converting landscape and weather}

To set the pleasure of activities after your workings day: surfing, game, seaside ... why not take the possibility of a holiday Lifestyles all the year? The living environment and the weather play plenty on morale. The problems of everyday life may be speedy erased if in the back of you've got an idyllic life: sun, nature. Alternatively, now and again what one has idealized all his lifestyles seems now not to in shape us. So analyze your priorities cautiously earlier than choosing your vacation spot. Expatriation isn't always an innocuous decision that one takes in a single day.

\section{Open your mind to your children}

We speak of enrichment for you however if you have a Family, it is the possibility on your children to take advantage of this cultural blend, to study numerous languages. This enjoy that they will live out of the country will permit them an openness to be able to serve all of them their lives.

Meet new people

To leave is to make new buddies. It is a possibility to exchange, Analyze and improve each other. Whether with nearby people or foreign expatriates, the extra open and social you're, the extra you'll make new friends. Arriving in a new country will force you to be more open. Conversely, you may additionally learn how to go out on my own due to the fact you may always have evenings where you will now not realize what to do. That is some other way of coming across places and finally making encounters too.

\section{Changing your routine}

Even if all people says "run away," an ordinary usually sets in. it isn't always necessarily poor however its miles a consolation of life wherein one likes. So do no longer wait too long earlier than pushing your each day life. To achieve taking a step lower back for your existence and moving far away from it to live a new experience will simplest be more enriching for you.

\section{A. Statement of the Problem:}

All of the expatriates have some reasons and expectation for expatriation, however choice-making should be carefully taken into consideration. Expatriation is also a threat-taking system, so it is as much as you to prepare for it. Consider that for a successful Expatriation, it's miles important. This paper ambition to check and extend the qualitative findings on reasons to expatriate and relate them to work consequences. Inspecting how reasons and expectation to expatriate may additionally affect work consequences.

\section{B. Objectives of the Study:}

1. To find out the expectation of the Tamil expatriates in UAE

2. To know the experience of the UAE Tamil expatriates

3. To compare the expectation and experience of the UAE Tamil expatriates

4. To give suggestion to the expatriates

\section{Scope of the Study}

The focus of the study is expectation of the expatriates, it only cover with reason and expectation of the construction work expatriates but it does not cover expectation process.

\section{METHODOLOGY}

This research was conducted from construction workers working in the selected construction companies in Dubai. The methodology of the study is opinion survey, the questionnaire were used for opinion survey.

\section{A. Data Collection}

The primary and secondary data were collected for this study. B. Area of the Study

The respondents Tamil expatriates construction workers who are working in the construction companies situated in Dubai. C. Statistical Tool Used

Mean Standard deviation ANOVA tools used for this study. D. Hypothesis

$\mathrm{H}_{0}$ - Expectation no differ according to age of expatriates

$\mathrm{H}_{0}$ - Reason of expatriation no differ according to age of expatriates

$\mathrm{H}_{0}$ - Experience no differ according to age of expatriation

\section{RESULTS}

Table 3.1

$\mathrm{H}_{0}$ - Reason of expatriation no differ according to age of expatriates ANOVA

\begin{tabular}{|c|c|c|c|c|c|c|}
\hline $\begin{array}{l}\text { Reason for } \\
\text { expatriation }\end{array}$ & & $\begin{array}{l}\text { Sum of } \\
\text { Squares }\end{array}$ & df & $\begin{array}{l}\text { Mean } \\
\text { Square }\end{array}$ & F & Sig. \\
\hline $\begin{array}{l}\text { Lack of } \\
\text { employment }\end{array}$ & $\begin{array}{l}\text { Between Groups } \\
\text { Within Groups } \\
\text { Total }\end{array}$ & $\begin{array}{r}.729 \\
11.005 \\
11.733\end{array}$ & $\begin{array}{r}4 \\
55 \\
59\end{array}$ & $\begin{array}{l}.182 \\
.200\end{array}$ & .910 & .464 \\
\hline $\begin{array}{l}\text { Overcome } \\
\text { economic } \\
\text { constrain }\end{array}$ & $\begin{array}{l}\text { Between Groups } \\
\text { Within Groups } \\
\text { Total }\end{array}$ & $\begin{array}{r}.102 \\
2.748 \\
2.850\end{array}$ & $\begin{array}{r}4 \\
55 \\
59\end{array}$ & $\begin{array}{l}.026 \\
.050\end{array}$ & .511 & .728 \\
\hline $\begin{array}{l}\text { Improve Financial } \\
\text { Condition }\end{array}$ & $\begin{array}{l}\text { Between Groups } \\
\text { Within Groups } \\
\text { Total }\end{array}$ & $\begin{array}{r}.595 \\
12.005 \\
12.600\end{array}$ & $\begin{array}{r}4 \\
55 \\
59\end{array}$ & $\begin{array}{l}.149 \\
.218\end{array}$ & .682 & .608 \\
\hline $\begin{array}{l}\text { Enjoy living } \\
\text { condition of UAE }\end{array}$ & $\begin{array}{l}\text { Between Groups } \\
\text { Within Groups } \\
\text { Total }\end{array}$ & $\begin{array}{r}.291 \\
2.559 \\
2.850\end{array}$ & $\begin{array}{r}4 \\
55 \\
59\end{array}$ & $\begin{array}{l}.073 \\
.047\end{array}$ & 1.566 & .196 \\
\hline $\begin{array}{l}\text { Dispute in } \\
\text { hometown }\end{array}$ & $\begin{array}{l}\text { Between Groups } \\
\text { Within Groups } \\
\text { Total }\end{array}$ & $\begin{array}{r}.060 \\
1.873 \\
1.933\end{array}$ & $\begin{array}{r}4 \\
55 \\
59\end{array}$ & $\begin{array}{l}.015 \\
.034\end{array}$ & .443 & .777 \\
\hline $\begin{array}{l}\text { Career } \\
\text { development }\end{array}$ & $\begin{array}{l}\text { Between Groups } \\
\text { Within Groups } \\
\text { Total }\end{array}$ & $\begin{array}{l}1.342 \\
6.991 \\
8.333\end{array}$ & $\begin{array}{r}4 \\
55 \\
59\end{array}$ & $\begin{array}{l}.336 \\
.127\end{array}$ & 2.640 & .043 \\
\hline
\end{tabular}

Interpretation: 
The result of this analysis of variance suggests that statistically responses on account of all factors, that is lack of employment, overcome economic constrain, improve financial condition, enjoying living condition, dispute in hometown, career development are not significant. The $\mathrm{P}$-value of this variable is higher than 0.05 at 5 percentage level. The statistical inference of this exercise is accept of the null hypothesis when the outcome is statistically significant with $\mathrm{P}$-value higher than 0.05 .

Table 3.2

$\mathrm{H}_{0}$ - Expectation no differ according to age of expatriates

\begin{tabular}{|c|c|c|c|c|c|c|}
\hline \\
\hline & & $\begin{array}{l}\text { Sam ef } \\
\text { Squasea }\end{array}$ & $\mathrm{df}$ & $\begin{array}{l}\mathrm{Men} \\
\mathrm{Squ}=\mathrm{m}\end{array}$ & $\mathrm{F}$ & Siz. \\
\hline \multirow{3}{*}{ 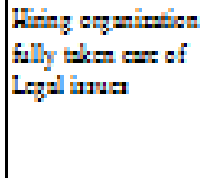 } & $\begin{array}{l}\text { Betwern } \\
\text { Geugy }\end{array}$ & .758 & 4 & .180 & 1.687 & 166 \\
\hline & Within Gropy & 6.176 & 55 & .112 & & \\
\hline & Tetal & 6.933 & 50 & & & \\
\hline \multirow{3}{*}{ 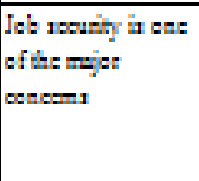 } & $\begin{array}{l}\text { Betwem } \\
\text { Geugn }\end{array}$ & .000 & 4 & .000 & & \\
\hline & Within Gropg & .000 & 55 & .000 & & \\
\hline & Tetal & .000 & 50 & & & \\
\hline \multirow[t]{3}{*}{ Finencial Bencfa } & $\begin{array}{l}\text { Between } \\
\text { Gengor }\end{array}$ & .000 & 4 & .000 & & \\
\hline & Within Gespi & .000 & 55 & .000 & & \\
\hline & Tetal & .000 & 50 & & & \\
\hline \multirow[t]{3}{*}{ Bencfat to finly } & $\begin{array}{l}\text { Betwes: } \\
\text { Grougn }\end{array}$ & 310 & 4 & .077 & 1.245 & 303 \\
\hline & Whin Geugi & 3.423 & 55 & .062 & & \\
\hline & Tetal & 3.793 & 50 & & & \\
\hline \multirow[t]{3}{*}{$\begin{array}{l}\text { Geod sduetion of } \\
\text { thilden }\end{array}$} & $\begin{array}{l}\text { Betwene } \\
\text { Geugy }\end{array}$ & $.50 !$ & 4 & .148 & $t .28:$ & 280 \\
\hline & Wain Grovi & 6.342 & 55 & .115 & & \\
\hline & Tetal & 6.039 & 50 & & & \\
\hline \multirow[t]{3}{*}{$\begin{array}{l}\text { Geed } \\
\text { Aesemmedatise }\end{array}$} & $\begin{array}{l}\text { Betwern } \\
\text { Gougy }\end{array}$ & 1.136 & 4 & .284 & 1.846 & 193 \\
\hline & Within Gespi & 8.464 & 55 & .154 & & \\
\hline & Tetal & 9.600 & 58 & & & \\
\hline \multirow[t]{3}{*}{ Well esmgenatisn } & $\begin{array}{l}\text { Betwese } \\
\text { Mreugi }\end{array}$ & .740 & 4 & .185 & 1.642 & 177 \\
\hline & Within Gespi & 6.104 & 55 & .113 & & \\
\hline & Tetal & 6.939 & 50 & & & \\
\hline \multirow[t]{3}{*}{ Pear nopest } & $\begin{array}{l}\text { Bewern } \\
\text { Geupi }\end{array}$ & .501 & 4 & .43 & $1.28 t$ & 280 \\
\hline & Within Grougi & 6.342 & 55 & .115 & & \\
\hline & Tetal & 6.093 & 58 & & & \\
\hline \multirow[t]{3}{*}{$\begin{array}{l}\text { Geed helt exr } \\
\text { folitia }\end{array}$} & $\begin{array}{l}\text { Betwer } \\
\text { Geugy }\end{array}$ & 1.196 & 4 & .284 & 1.846 & 193 \\
\hline & Within Grosy & 8.464 & 55 & .154 & & \\
\hline & Tetal & 8.600 & 50 & & & \\
\hline \multirow[t]{3}{*}{$\begin{array}{l}\text { Geed wetking } \\
\text { evimenmest }\end{array}$} & $\begin{array}{l}\text { Betwer } \\
\text { Geugr }\end{array}$ & .408 & 4 & .102 & .774 & 547 \\
\hline & Within Gespi & 7.242 & 55 & .132 & & \\
\hline & Tetal & 7.650 & 50 & & & \\
\hline
\end{tabular}

Interpretation:
The result of this analysis of variance suggests that statistically responses on account of all factors, that is Hiring organization fully taken care of Legal issues, Job security is one of the major concerns, Financial Benefits, Benefits to family, Good education of children, Good Accommodation, Well compensation, Peer support, Good health care facilities and Good working environment are not significant. The $\mathrm{P}$-value of this variable is higher than 0.05 at 5 percentage level. The statistical inference of this exercise is accept of the null hypothesis when the outcome is statistically significant with P-value higher than 0.05 .

Table 3.3

$\mathrm{H}_{0}-$ Experience no differ according to age of expatriation

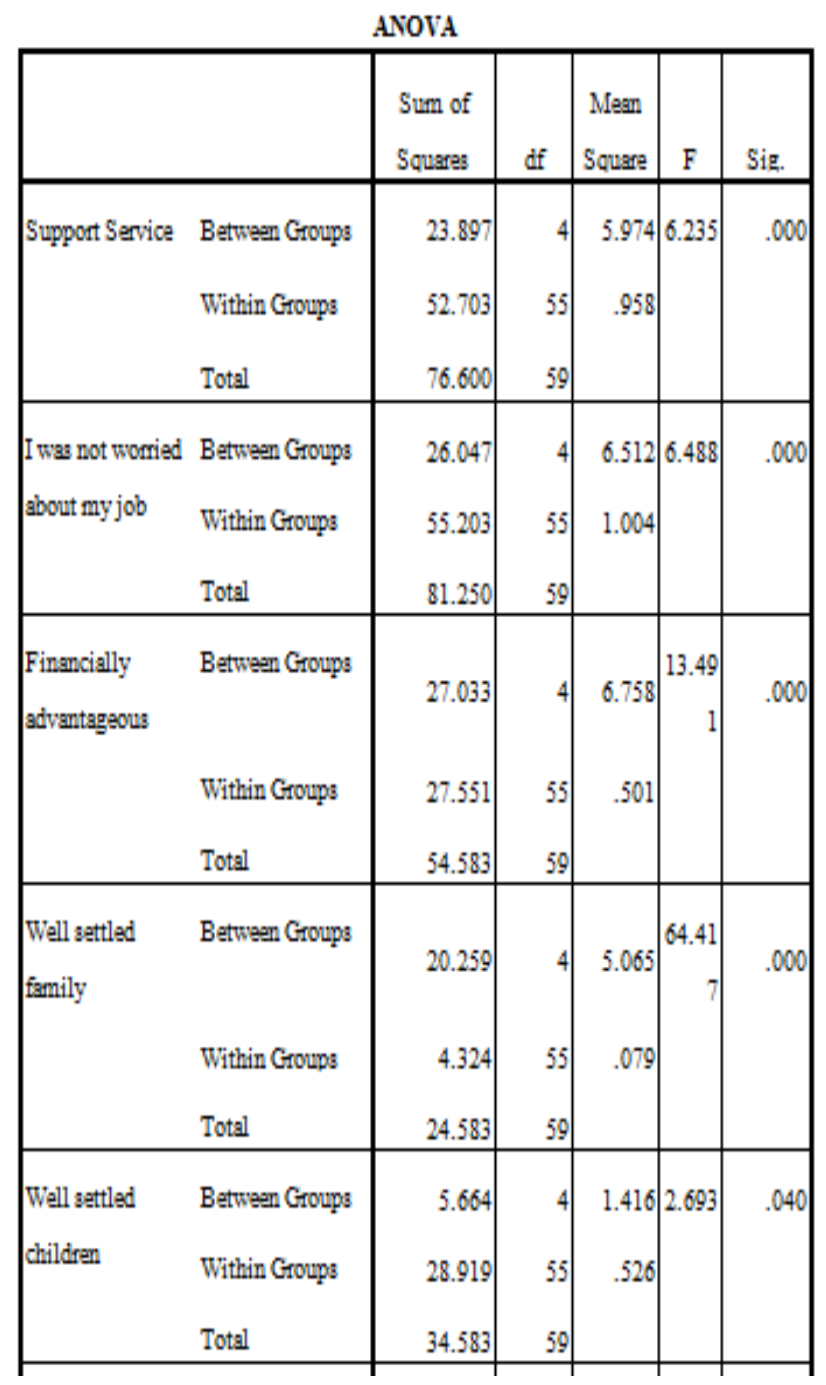




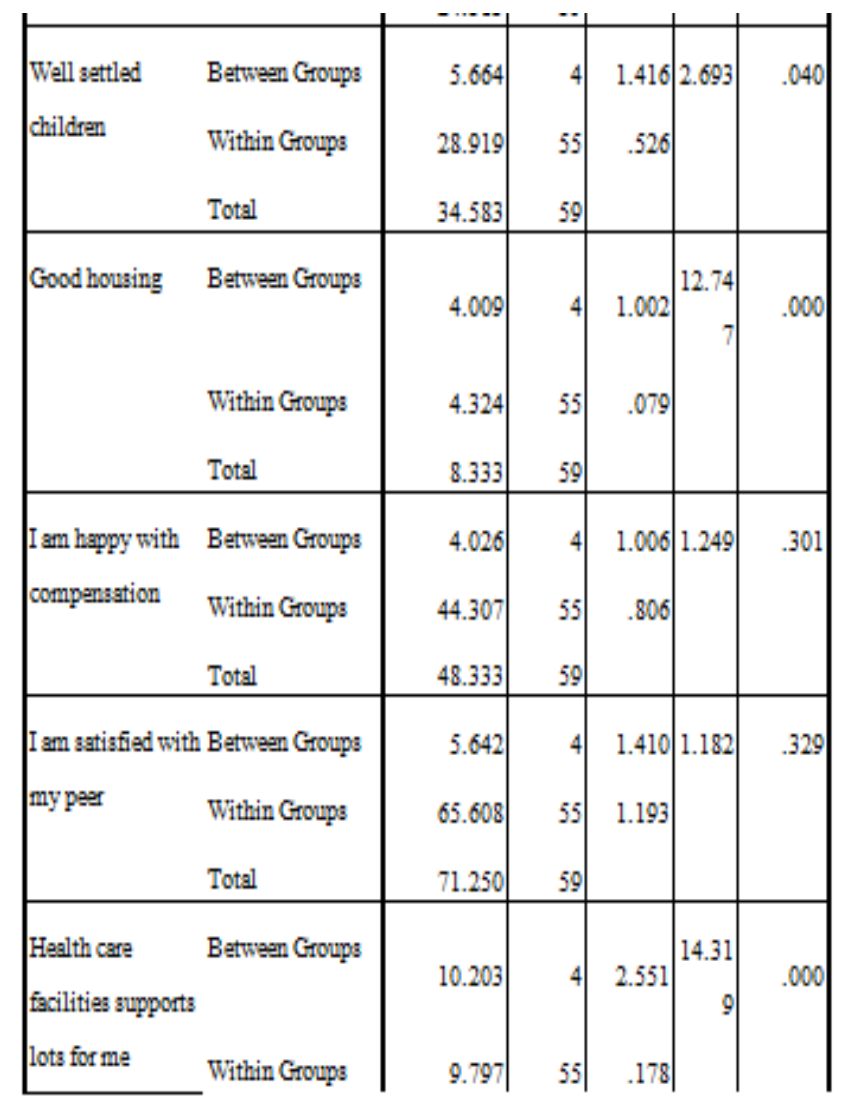

\begin{tabular}{|ll|r|r|r|r|r|}
\hline & Total & 20.000 & 59 & & & \\
\hline Life style is & Between Groups & 6.132 & 4 & 1.533 & .991 & .420 \\
changed & Within Groups & 85.118 & 55 & 1.548 & & \\
& Total & 91.250 & 59 & & & \\
\hline I am happy with & Between Groups & 9.730 & 4 & 2.432 & 1.482 & .220 \\
my working & Within Groups & 90.270 & 55 & 1.641 & & \\
environment & Total & 100.000 & 59 & & & \\
\hline
\end{tabular}

\section{Interpretation:}

The result of these analysis of variance suggest that statistically responses on account of I am happy with compensation, I am satisfied with my peer, Life style is changed and I am happy with my working environment are not significant. The $\mathrm{P}$-value of this variable is higher than 0.05 at 5 percentage level. The statistical inference of this exercise is accept of the null hypothesis when the outcome is statistically significant with P-value higher than 0.05 .

\section{DISCUSSION}

The reason of the expatriation of the Tamil expatriates who are working in construction companies is same that means the reason of expatriation is earn money to overcome from their economic constrain, Improve financial condition and lack of job opportunity in hometown.

The expectation of the Tamil construction work expatriates also same that are hiring organization fully taken care of legal issues, Job security is one of the major concerns, Financial Benefits, Benefits to family, Good education of children, Good Accommodation, Well compensation, Peer support,
Good health care facilities and Good working environment are not significant.

The Tamil expatriates experience is not satisfied with the Support Service they are worried about their job security, financially advantageous, well settled family, well settled children, good housing and Health care facilities.

\section{Suggestion:}

The construction companies can reshuffle its support service of employees or reshaped their facilities providing to their workers. The effective companies can use straight forward process to fulfill expectation of their employees

\section{V.CONCLUSION}

The companies which are try to satisfy expectation of the employees and try to solve the employees problem that companies are suspended to capture tomorrow's goal, they can reach executive development that they will create financially successful.

\section{REFERENCES}

[1] Sebastian Reiche, Why would you go abroad? Professional vs. personal reasons to accept an expatriate assignment, IESE Business School University of Navarra, 2011

[2] Mondassur, 10 good reasons to go abroad, Travel insurance \& expat insurance expert.

[3] Expectations vs. reality of expatriate support activities in the case company X Sanna Tilli, Bachelor's Thesis Degree Programme in International Business, 2011.

[4] Gibson. C, Common Expectations of Expats-to-Be, Expat Insider The International Survey, 2015.

[5] Selmer. J and Lauring J, Reasons to expatriate and work outcomes of self-initiated expatriates, Emarald Sight, 2012 